\title{
Rekomendasi Makanan untuk Ibu Hamil Menggunakan Algoritma Genetika
}

\section{(Food Recommendations for Pregnant Women Using Genetic Algorithms)}

\author{
Nadya Satya Handayani ${ }^{1}$, Sri Kusumadewi ${ }^{2}$, Edi Fitriyanto ${ }^{3}$ \\ ${ }^{1}$ Jurusan Teknik Informatika, Fakultas Teknologi Industri, Universitas Islam Indonesia \\ ${ }^{2}$ Fakultas Teknologi Industri, Universitas Islam Indonesia \\ ${ }^{3}$ Fakultas Kedokteran, Universitas Islam Indonesia \\ 116917216 estudents.uii.ac.id \\ ${ }^{2}$ cicieduii.ac.id \\ $3017110417 @ u i$ ac.id
}

\begin{abstract}
Abstrak - Kondisi kandungan yang baik menjadi sebuah keinginan bagi setiap ibu hamil. Menjaga kondisi tersebut dapat dilakukan dengan menjaga pola makan dan mengkonsumsi makanan yang tepat dan sesuai dengan kebutuhan gizi. Kebutuhan gizi ibu hamil dapat dihitung menggunakan formula awal Harris Bennedict. Lalu dapat dilanjutkan dengan menentukan kebutuhan kalori berdasarkan aktivitas dan trimester kehamilan ibu hamil hingga menghasilkan total energy expenditure (TEE) yang sesuai untuk ibu hamil. Rekomendasi menu makanan ibu hamil diperoleh menggunakan algoritma genetika. Algoritma genetika merupakan metode yang dapat memberikan solusi dalam pemecahan masalah heuristik dan banyak digunakan untuk memecahkan masalah optimasi. Untuk mendapatkan rekomendasi makanan yang optimal, langkah awal yang dilakukan yaitu menentukan parameter algoritma genetika. Setelah itu, melakukan kombinasi kromosom secara random. Proses selajutnya yaitu dilakukan evaluasi menggunakan metode roda rolet, lalu crossover menggunakan metode single point crossover dan dilakukan proses mutasi. Langkah terakhir melakukan seleksi menggunakan metode elitis sehingga memenuhi kondisi berhenti. Hasil yang diperoleh yaitu rekomendasi makanan untuk ibu hamil dalam satu hari yang terdiri dari 5 waktu makan yaitu sarapan, snack pagi, makan siang, snack sore dan makan malam. Berdasarkan pengujian validasi yang dilakukan dengan pakar, hasil kalori yang diperoleh sebesar 91\% mendekati jumlah kalori yang sesuai dengan kebutuhan dan $9 \%$ tidak sesuai dengan kalori yang dibutuhkan oleh ibu hamil, karena memiliki perbedaan kalori yang cukup jauh berbeda.
\end{abstract}

Kata-kata kunci: gizi ibu hamil, Harris Bennedict, algoritma genetika

Abstract - A good womb condition is a hope for every pregnant women. To maintain these conditions can be done by maintaining a healthy diet and consuming the right foods which contain adequate nutrition. Nutritional needs of pregnant women can be calculated by using Harris Bennedict formulation. Then, it can be continued by determining calorie requirements according activity and trimester of pregnancy until it produces total energy expenditure (TEE) which is suitable for pregnant women. Menu reccomendation for pregnant women obtained by using genetic algorithms. Genetic algorithms is a method which can provide solutions in heuristik problem solving, and widely used to solve optimization problems. To get optimal food reccomedation, the first step to do is determine parameters of genetic algorithm, then, make a random combination of chromosomes. The next step is make an evaluation by using roda rolet method, then, crossover using single point crossover method and carried out the mutation process. The last step in conducting the selection is to use the elistist method so that it meets the stop condition. The results obtained are food recommendations for pregnant women in one day, which consist of 5 meals, namely breakfast, morning snack, lunch, afternoon snack and dinner. Based on validation testing conducted by experts, the calorie yield obtained by $91 \%$ approaching the number of calories according to the needs, and $9 \%$ does not match the calories needed by pregnant women, it caused by a different calorie which quite difference.

Keywords: Nutrition of pregnant women, Harris Bennedict, Genetic algorithm

\section{PENDAHULUAN}

Mayoritas ibu hamil datang kedokter kandungan untuk memeriksakan kesehatan kandungan. Tidak hanya kesehatan kandungan, gizi dan nutrisi ibu hamil juga harus terpenuhi selama masa kehamilan. Karena gizi ibu hamil merupakan masalah kecil yang dapat mempengaruhi kondisi bayi di dalam kandungan [1]. 
Gizi yang dibutuhkan ibu hamil berbeda setiap trimester, pada trimester I (1-3 bulan) dibutuhkan makanan untuk pembentukan organ janin dan pada Trimester II (4-6 bulan) dan III (7-9 bulan) untuk pertumbuhan dan perkembangan janin. Setiap trimester makanan yang dikonsumsi ibu hamil harus mengandung karbohidrat, protein, lemak, vitamin, dan mineral [2].

Gizi dalam kehamilan sangat berpengaruh dengan kondisi klinis ibu hamil, jika gizi tidak terpenuhi dengan tepat dapat menimbulkan beberapa dampak yaitu apabila ibu hamil kekurangan gizi pada masa kehamilan dapat mengakibatkan Kekurangan Energi Kronis (KEK) dan anemia pada ibu hamil [3]. Dampak lainnya dari pengaruh gizi ibu hamil yaitu hipertensi dan diabetes gestasional, hal tersebut disebabkan karena overweight dan riwayat hipertensi ibu hamil [4]. Tidak hanya pada ibu hamil masalah gizi juga dapat berdampak pada bayi yang ada di dalam kandungan. Beberapa kasus terjadi, bayi yang lahir cukup bulan tetapi gizi tidak tercukupi memberikan dampak bayi lahir dibawah 2500 gram atau mengalami berat badan lahir rendah (BBLR) [5]. Menurut Kemenkes, tidak hanya BBLR bayi yang kekurangan nutrisi makanan sejak didalam kandungan juga dapat menyebabkan stunting pada anak ketika lahir. Stunting merupakan kondisi gagal pertumbuhan tubuh dan otak pada anak akibat kekurangan gizi kronik sehingga dapat mengakibatkan tinggi tubuh anak kurang dari standar deviasi yang sudah ditentukan dan memiliki keterlambatan dalam berpikir[6]. Faktor lainnya yaitu penyebab bayi kekurangan gizi yaitu rendahnya akses terhadap makanan bergizi, rendahnya asupan vitamin, mineral, dan buruknya keragaman pangan dan sumber protein hewani.

Terdapat beberapa penelitian yang berkaitan dengan penelitian ini yaitu desain model sistem pakar gizi kehamilan yang dirancang untuk memberikan kemudahan bagi ibu dalam menentukan menu makanan sehat berdasarkan usia ibu, trisemester, usia kandungan, IMT, berat badan dan tinggi badan dan kebutuhan kalori menggunakan metode cooper, agar mempermudah ibu dalam mengontrol pola makan sehat selama kehamilan sehingga tercapai berat badan ideal [7]. Penelitian lainnya membahas tentang optimasi gizi untuk ibu hamil yang mana kalori untuk ibu hami dihitung menggunakan metode cooper dan untuk mendapatkan solusi yang optimum menggunakan hybrid algoritma genetika (GA) dan simulated annealing (SA) [8]. Selanjutnya penelitian tentang membangun sebuah aplikasi sistem informasi untuk dapat menunjang angka kecukupan gizi ibu hamil dalam bentuk pemilihan alternatif bahan dan jenis makanan yang dapat dikonsumsi sehari-hari disertai dengan kandungan kecukupan gizinya, sehingga para ibu hamil mampu mengatur pola konsumsi hariannya dan secara otomatis kandungan gizinya pun dapat terperhatikan [9].

Berdasarkan permasalahan yang terjadi, untuk memberikan rekomendasi makanan yang optimal dan variatif untuk ibu hamil, dibutuhkan algoritma yang sesuai. Salah satu algoritma yang dapat memberikan rekomendasi makanan yang optimal dan variatif adalah algoritma genetika [10]. Algoritma genetika dapat memberikan rekomendasi makanan untuk ibu hamil yang sesuai dengan perkiraan jumlah kalori, karbohidrat, protein dan lemak yang dibutuhkan oleh ibu hamil dalam satu hari. Perkiraan jumlah kalori yang harus dikonsumsi ibu hamil dapat dihitung menggunakan formula awal Harris Benedict. Formula tersebut akan menghasilkan basal energy expenditure (BEE) untuk ibu hamil [11]. Variabel yang dibutuhkan untuk menghitung BEE yaitu data berat badan, tinggi badan, usia ibu hamil dan usia kandungan. Setelah itu menentukan aktivitas fisik yang dilakukan oleh ibu hamil dalam satu hari dan menghitung nilai sesuai trimester kehamilan, sehingga menghasilkan total energy expenditure (TEE) yang harus dikonsumsi oleh ibu hamil dalam satu hari. Dengan adanya sistem tersebut diharapkan dapat memberikan rekomendasi makanan untuk ibu hamil sesuai dengan trimester kehamilan, jumlah kalori, aktivitas dan penyakit ibu hamil untuk mencapai kehamilan yang sehat.

\section{METODE}

Penelitian ini dilakukan dengan beberapa langkah penelitian untuk dapat mengetahui gambaran dan rincian yang dibuat secara sistematis dan dapat dijadikan pedoman yang jelas dalam menyelesaikan permasalahan, serta membuat analisis terhadap hasil penelitian. Langkah-langkah penelitian terdiri dari identifikasi masalah, pengumpulan data, permodelan, penembangan sistem dan pengujian. Langkah tersebut dapat dilihat pada gambar 1.

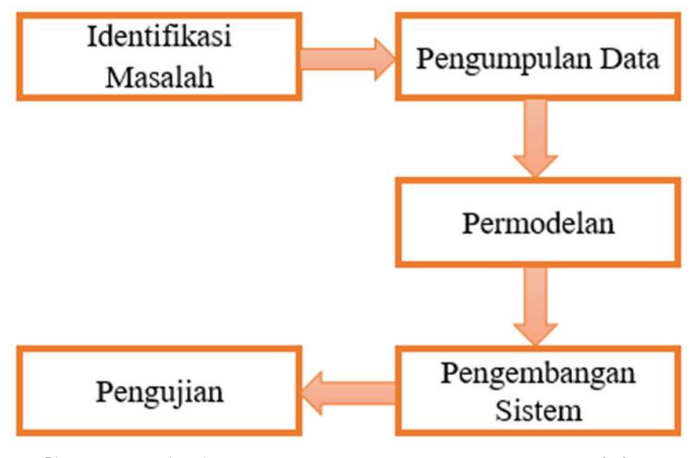

Gambar 1. Alur Langkah-langkah Penelitian 
Langkah-langkah yang dilakukan dalam penelitian ini yaitu:

A. Proses identifikasi masalah dilakukan dengan cara melakukan wawancara kapada pakar terkait permasalahan yang terjadi pada gizi ibu hamil.

$B$. Data makanan diperoleh dari Data Komposisi Bahan Makanan (DKBM) 2017 sebagai rekomendasi makanan untuk ibu hamil. Observasi dilakukan dengan cara mengambil data hasil pemeriksaan kehamilan (antenatal care) kepada petugas Pondok Bersalin Desa (Polindes) Puskesmas Air Manjuto dan Bidan setempat di wilayah Puskesmas Air Manjuto yang berkaitan dengan variabel-variabel input. Dan tahap wawancara dilakukan dengan dokter spesialis kandungan dan ahli gizi.

C. Selanjutnya permodelan, permodelan merupakan tahapan yang dilakukan untuk membangun sistem, permodelan sistem dibagi menajadi analisis gizi dan analisi metode. Analisis gizi dilakukan dengan penentuan jumlah kalori ibu hamil menggunakan formula dasar Harris Benedict. Setelah mendapatkan kalori ibu hamil, data kalori ibu hamil dianalisis menggunakan metode algoritma genetika untuk menyusunan menu makanan ibu hamil yang optimal dan variatif.

D. Langkah selanjutnya yaitu pengembangan sistem dilakukan dengan menganalisis kebutuhan, membuat perancangan sistem dan mengiplementasikan sistem. Analisis kebutuhan dapat dilakukan dengan pengumpulan data, perancangan sistem yang dilakukan dengan membuat flowchart, membangun database sistem, dan membuat perancangan interface.

E. Pengujian dilakukan dengan melakukan uji validitas sistem untuk melihat rekomendasi makanan yang diberikan sesuai dengan kebetuhan gizi ibu hamil.

\section{HASIL DAN PEMBAHASAN}

\section{A. Model Pengambilan Keputusan}

Model pengambilan keputusan untuk memberikan rekomendasi menu makanan kepada ibu hamil dimulai dari menginputkan data antenatal care lalu diproses untuk perhitungan kalori. Setelah itu proses yang dilakukan yaitu rekomendasi makanan yang mengahasilkan saran menu makanan untuk ibu hamil. Model pengambilan keputusan untuk memberikan rekomendasi makanan untuk ibu hamil dapat digambarkan pada gambar 2 .

Langkah pertama yang dilakukan untuk memberikan rekomendasi makanan yaitu menginputkan data antenatal care. Data antenatal care yang dibutuhkan yaitu data pemeriksaan ibu hamil normal, anemia, diabetes gestasional dan hipertensi. Variabel-variabel pemeriksaan yang dibutuhkan yaitu usia ibu hamil, berat badan, tinggi badan, usia kandungan, trimester kehamilan, kadar gula, tekanan darah, kadar hemoglobin dan kondisi klinis ibu hamil. Setelah itu dilakukan proses perhitungan kalori menggunakan formula dasar harris bennedict, setelah itu menghitung kalori berdasarkan aktivitas (Tabel 1) dan trimester kehamilan sehingga menghasilkan total energi expenditure (TEE) yang merupakan perkiraan total kalori yang harus dikonsumsi oleh ibu hamil dalam 1 hari. Hasil perkiraan kalori tersebut akan menjadi acuan untuk menentukan rekomendasi makanan kepada ibu hamil menggunakan metode Algoritma Genetika. Proses untuk memberikan rekomendasi makanan dimulai dengan merepresentasikan kromosom yang akan digunakan, menginisialisasi individu awal, melakukan evalusi kromosom, setelah itu hasil evaluasi dilakukan seleksi untuk mendapatkan populasi baru, lalu populasi baru akan dilakukan crossover dan mutasi. Saran menu makanan ibu hamil diperoleh dari kondisi akhir dari proses algoritma genetika. Kromosom terbaik yang akan menjadi rekomendasi makanan untuk ibu hamil. Jika makanan yang direkomendasikan ada yang tidak digemari atau ibu hamil tidak ingin memakannya ibu hamil dapat memilih makanan yang lainnya.

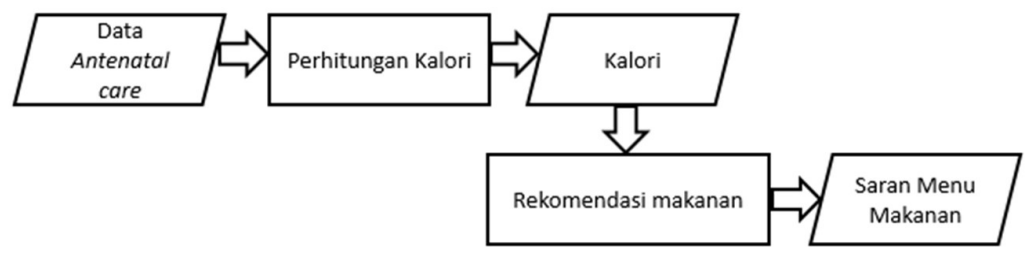

Gambar 2. Model Pengambilan Keputusan Rekomendasi Makanan 
TABEL I

PENENTUAN AKTIVITAS

\begin{tabular}{clccc}
\hline No & Nama Aktivitas & PAR & W & PAR * W \\
\hline 1 & Memasak & 1 & 2.1 & 2.1 \\
2 & Berjalan & 1 & 3.2 & 3.2 \\
3 & Makan & 1 & 1.5 & 1.5 \\
4 & Tidur & 7 & 1 & 7 \\
5 & Perawatan diri & 1 & 2.3 & 2.3 \\
\hline$\sum(\boldsymbol{P A R} * \boldsymbol{W})$ & & & 16.1 \\
\hline PAL & & & $\frac{16.1}{24}=0.67$
\end{tabular}

Keterangan:

$\mathrm{PAL}=$ Phisical Activity Level

BEE = Basal Energy Expenditure

TEE = Total Energy Expenditure

$\mathrm{KF} \quad=$ Kegiatan Fisik

$\mathrm{NKF}=$ Nilai Kegiatan Fisik

FIT $=$ Food Induced Thermogenesis

$\mathrm{T}=$ Trimester

TB = Tinggi Badan

$\mathrm{BB}=$ Berat Badan

$\mathrm{U} \quad=$ Usia Ibu Hamil

Kalori yang dibutuhkan oleh ibu hamil dapat dihitung menggunakan rumus Harris Bennedict (persamaan 1) [13]:

$\mathrm{BEE}=655+(9,6(\mathrm{BB}))+(1,4(\mathrm{~TB}))-(4,7(\mathrm{U})) \ldots(1)$ $=1430,8$

Berdasarkan perhitungan pada tabel 1 diperoleh nilai PAL 0.67 maka aktivitas yang dilakukan ibu hamil termasuk pada kategori "sangat ringan" dan nilai kegiatan fisik (NKF) adalah 10\%. Setelah mendapatkan BEE (Basal Energy Expenditure), akan dicari perhitungan kalori ibu hamil berdasarkan kegiatan fisik dan trimester kehamilan menggunakan persamaan 2 [14]. $\mathrm{KF}=\mathrm{NKF} \times \mathrm{BEE}$

$=143,08$

Ibu hamil dalam contoh kasus ini usia kehamilannya yaitu 18 minggu yang termasuk ke dalam trimester(T) 2 kehamilan. Maka dapat dihitung Food Induced Thermogenesis (FIT) pada persamaan 3.

$\mathrm{FIT}=\mathrm{T} \times(\mathrm{BEE}+\mathrm{KF}) \ldots \ldots . .(3)$

$$
=314,776
$$

Hasil akhir kalori ibu hamil dapat dicari menggunakan rumus Total Energy Expenditure (TEE) berdasarkan persamaan 4[14].

TEE ibu hamil $=\mathrm{BEE}+\mathrm{KF}+\mathrm{FIT}+100$

$$
=1988,65 \approx 2000 \mathrm{kkal}
$$

Kalori hasil perhitungan dibagi menjadi Karbohidrat $65 \%$ yaitu 325 gram, Protein $15 \%$ yaitu 75 gram dan
Lemak $20 \%$ yaitu 44,44 gram. Hasil pembagian kalori dikonversi dari satuan kkal ke gram. 1 gram protein mengandung 4 kalori, 1 gram lemak mengandung 9 kalori dan 1 gram karbohidrat mengandung 4 kalori.

\section{B. Rekomendasi Makanan Menggunakan Algoritma Genetika}

Penentuan menu makanan ibu hamil dapat digambarkan pada gambar 3 .

Proses penentuan menu makanan untuk ibu hamil dimulai dari menginputkan data kebutuhan gizi dan parameter algoritma genetika, lalu dilanjutkan dengan proses inisialisasi populasi, evaluasi, seleksi menggunakan metode roda rolet, crossover, mutasi, seleksi elitisi, hingga mendapatkan kromosom terbaik.

1) Representasi Kromosom. Representasi kromosom yang digunakan adalah representasi bilangan integer. Setiap angka yang ada di dalam kromosom dapat merepresentasikan indeks yang terdapat dalam data daftar bahan makanan DKBM. Kromosom-kromosom tersebut berisikan nomor makanan yang direkomendasikan untuk ibu hamil normal, anemia, hipertensi dan diabetes gestasional. Kromosom 1 hari memiliki gen sebanyak 16. Contoh representasi kromosom dapat dilihat pada tabel 2.

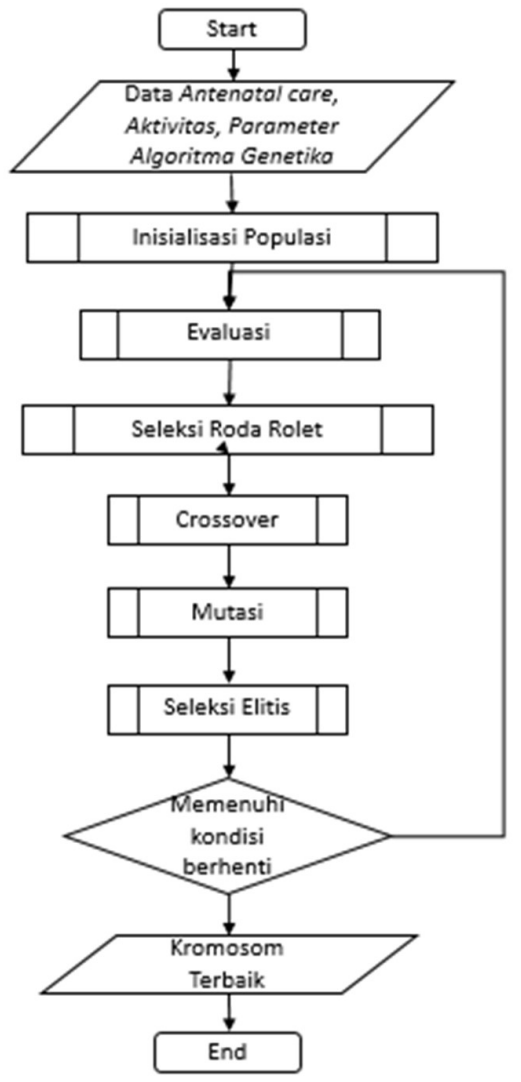

Gambar 3. Alur Algoritma Genetika 
2) Parameter Algoritma Genetika. Parameter algoritma genetika yang digunakan yaitu ukuran populasi 100 , banyak generasi 500 , peluang crossover (PC) 0,7 dan peluang mutasi (PM) 0,3.

3) Insialisasi Populasi. Inisialisasi populasi awal harus sesuai dengan parameter awal yang sudah ditentukan, yaitu membangkitkan 100 individu berdasarkan ukuran populasi yang mana setiap kromosom memiliki nilai random/acak sebanyak 16 dari menu makanan yang memiliki zat gizi karbohidrat, protein dan lemak. Adapun contoh inisialisasi populasi awal dapat dilihat pada tabel 3 .

4) Evaluasi. Proses evaluasi dilakukan dengan menentukan fungsi objektif. Fungsi objektif berguna untuk mencari solusi terbaik dari suatu permasalahan. Untuk dapat menyelesaikan masalah optimasi digunakan fungsi pinalti untuk memenuhi syarat-syarat yang sudah ditentukan . Fungsi objektif dapat ditentukan pada persamaan 5 [15].

$f_{(o b j)}=$ pinalti kalori + pinalti karbohidrat + pinalti protein + pinalti lemak

$f_{(o b j)}=202,34$

a) Pinalti Kalori $=[$ Total kalori - total kebutuhan kalori; jika Total kalori $>$ total kebutuhan kalori atau Total kebutuhan kalori - total kalori; jika Total kalori $<=$ total kebutuhan kalori]

Pinalti Kalori $=2000-1965=35$

b) Pinalti Karbohidrat $=[$ Total karbohidrat - total kebutuhan karbohidrat; jika Total karbohidrat > total kebutuhan karbohidrat atau Total kebutuhan karbohidrat - total karbohidrat; jika Total karbohidrat $<=$ total kebutuhan karbohidrat]

TABEL II

KROMOSOM

\begin{tabular}{lccccccccccccccc}
\hline & \multicolumn{1}{c}{ Sarapan } & \multicolumn{4}{c}{ Snack Pagi } & \multicolumn{4}{c}{ Makan Siang } & \multicolumn{3}{c}{ Snack Sore } & \multicolumn{3}{c}{ Makan Malam } \\
\hline MP & LP & SM & BH & MR & BH & MP & LP & SM & BH & MR & BH & MP & LP & SM & BH \\
7 & 12 & 23 & 43 & 107 & 61 & 44 & 72 & 25 & 20 & 100 & 30 & 50 & 11 & 17 & 26 \\
\hline
\end{tabular}

Keterangan:

MP = Makanan Pokok

LP $=$ Lauk-Pauk
Pinalti Karbohidrat $=375-222,5=152,5$

c) Pinalti protein $=[$ Total protein - total kebutuhan protein; jika Total protein $>$ total kebutuhan protein atau Total kebutuhan protein - total protein; jika Total protein $<=$ total kebutuhan protein]

Pinalti protein $=75-82,4=7,4$

d) Pinalti lemak $=$ Total lemak - total kebutuhan lemak; jika Total lemak > total kebutuhan lemak atau Total kebutuhan lemak - total lemak; jika Total lemak $<=$ total kebutuhan lemak]

Pinalti Lemak $=44,44-37=7,44$

Setelah mendapatkan nilai objektif, nilai fungsi fitness dapat ditentukan pada persamaan 6 .

Fitness $=\frac{1}{1+f_{(o b j)}}$

Fitness $=0,004917872$

Hasil fungsi objektif dan fungsi fitness dapat dilihat pada tabel 4 .

5) Seleksi Roda Rolet. Seleksi roda rolet dapat dilakukan dengan beberapa cara berikut:

a) Langkah pertama yang dilakukan yaitu menghitung nilai fitness berdasarkan rumus fungsi fitness, nilai fungsi fitness dapat dilihat pada tabel 4.

b) Menghitung nilai kumulatif

Nilai kumulatif dapat dihitung menggunakan persamaan 7 sehingga mendapatkan hasil seperti tabel 5 .

$K=K_{n}+F_{i+1}, \quad i=1 \ldots \ldots$ ukuran populasi, $n=$ 1 ......nilai kumulatif

TABEL III

INISIALISASI POPULASI

\begin{tabular}{ccccccccccccccccc}
\hline & \multicolumn{4}{c}{ Sarapan } & \multicolumn{4}{c}{ Snack Pagi } & \multicolumn{4}{c}{ Makan Siang } & \multicolumn{3}{c}{ Snack Sore } & \multicolumn{3}{c}{ Makan Malam } \\
\cline { 2 - 17 } & MP & LP & SM & BH & MR & BH & MP & LP & SM & BH & MR & BH & MP & LP & SM & BH \\
\hline 1 & 39 & 7 & 19 & 37 & 56 & 16 & 28 & 68 & 21 & 21 & 106 & 58 & 25 & 65 & 2 & 27 \\
2 & 47 & 21 & 4 & 2 & 11 & 1 & 24 & 6 & 16 & 74 & 1 & 54 & 27 & 25 & 1 & 74 \\
3 & 6 & 38 & 18 & 54 & 11 & 53 & 18 & 56 & 4 & 23 & 3 & 71 & 38 & 17 & 6 & 26 \\
4 & 30 & 51 & 28 & 54 & 21 & 4 & 49 & 47 & 24 & 63 & 51 & 54 & 2 & 18 & 9 & 66 \\
$\ldots$ & $\ldots$ & $\ldots$ & $\ldots$ & $\ldots$ & $\ldots$ & $\ldots$ & $\ldots$ & $\ldots$ & $\ldots$ & $\ldots$ & $\ldots$ & $\ldots$ & $\ldots$ & $\ldots$ & $\ldots$ & $\ldots$ \\
100 & 51 & 78 & 31 & 71 & 95 & 24 & 27 & 13 & 18 & 39 & 120 & 56 & 40 & 60 & 14 & 62 \\
\hline
\end{tabular}


TABEL IV

FUNGSI OBJEKTIF DAN FUNGSI FITNESS

\begin{tabular}{ccc}
\hline Kromosom & Fungsi Objektif & Fungsi Fitness \\
\hline 1 & 202,34 & 0,004917872 \\
2 & 384,44 & 0,002594438 \\
3 & 659,04 & 0,00151506 \\
4 & 736,56 & 0,001355822 \\
$\ldots$ & $\ldots$ & $\ldots$. \\
100 & 298,04 & 0,003344034 \\
\hline
\end{tabular}

TABEL V

NILAI KUMULATIF

\begin{tabular}{cc}
\hline Kromosom & Nilai Kumulatif \\
\hline 1 & 0,004917872 \\
2 & 0,007512309 \\
3 & 0,009027369 \\
4 & 0,010383191 \\
$\ldots$ & $\ldots \ldots$ \\
100 & 0,013727225 \\
\hline
\end{tabular}

c) Menentukan batas busur

Batas busur dapat ditentukan menggunakan persamaan 8 .

$B_{i}=\frac{K_{i}}{\text { total nilai fitness }}, i=1 \ldots \ldots$ ukuran populas $i$

(8)

$B_{1}=\frac{0,0193}{3,945}=0,00489$

d) Bangkitkan bilangan acak

Setelah mendapatkan batas busur, nilai batas busur setiap individu dirandom/diacak dari angka 0 sampai 1 sebanyak populasi.

e) Memilih Individu yang terseleksi
Berdasarkan nilai yang diacak dapat ditentukan kromosom yang terpilih dari 1 sampai sebanyak ukuran populasi dengan cara melihat nilai random $\leq$ nilai batas busur seperti pada tabel 6 .

Pada pembangkitan bilang acak yang pertama kromosom yang terpilih adalah kromosom ke-2, kromosom ke-4. Sehinggga populasi baru dapat dilihat pada tabel 7 .

6) Crossover. Metode yang digunakan untuk crossover yaitu metode Single Point Crossover. Pada metode ini, pemilihan induk dapat dilakukan dengan membangkitkan nilai acak sesuai peluang crossover $(\mathrm{Pc})$. Jumlah induk dapat dibangkitkan menggunakan persamaan 9.

Jumlah induk $=$ Peluang crossover $(\mathrm{Pc}) \mathrm{x}$ Ukuran

Populasi

Peluang Crossover $=0,7$

Jumlah induk $=70$

Setelah itu dilakukan penyilangan satu titik dari dua induk untuk mendapatkan offspring baru sehingga mendapatkan hasil pada tabel 8 .

TABEL VI

KROMOSOM YANG TERSELEKSI

\begin{tabular}{cc}
\hline Kromosom & Kromosom Terseleksi \\
\hline 1 & 2 \\
2 & 2 \\
3 & 4 \\
4 & 4 \\
$\ldots$ & $\ldots$ \\
100 & 2 \\
\hline
\end{tabular}

TABEL VII

HASIL SELEKSI RODA ROLET

\begin{tabular}{|c|c|c|c|c|c|c|c|c|c|c|c|c|c|c|c|c|}
\hline \multirow{2}{*}{ Kromosom } & \multicolumn{4}{|c|}{ Sarapan } & \multicolumn{2}{|c|}{ Snack Pagi } & \multicolumn{4}{|c|}{ Makan Siang } & \multicolumn{2}{|c|}{ Snack Sore } & \multicolumn{4}{|c|}{ Makan Malam } \\
\hline & MP & $\mathbf{L P}$ & SM & BH & MR & BH & MP & $\mathbf{L P}$ & SM & BH & MR & BH & MP & $\mathbf{L P}$ & SM & BH \\
\hline 1 & 47 & 21 & 4 & 2 & 11 & 1 & 24 & 6 & 16 & 74 & 1 & 54 & 27 & 25 & 1 & 74 \\
\hline 2 & 47 & 21 & 4 & 2 & 11 & 1 & 24 & 6 & 16 & 74 & 1 & 54 & 27 & 25 & 1 & 74 \\
\hline 3 & 30 & 51 & 28 & 54 & 21 & 4 & 49 & 47 & 24 & 63 & 51 & 54 & 2 & 18 & 9 & 66 \\
\hline 4 & 30 & 51 & 28 & 54 & 21 & 4 & 49 & 47 & 24 & 63 & 51 & 54 & 2 & 18 & 9 & 66 \\
\hline$\ldots$ & $\ldots$ & $\ldots$ & $\ldots$ & $\ldots$ & $\ldots$ & $\ldots$ & $\ldots$ & $\ldots$ & $\ldots$ & $\ldots$ & $\ldots$ & $\ldots$ & $\ldots$ & $\ldots$ & $\ldots$ & $\ldots$ \\
\hline 100 & 47 & 21 & 4 & 2 & 11 & 1 & 24 & 6 & 16 & 74 & 1 & 54 & 27 & 25 & 1 & 74 \\
\hline
\end{tabular}

TABEL VIII

SINGLE POINT CROSSOVER

\begin{tabular}{|c|c|c|c|c|c|c|c|c|c|c|c|c|c|c|c|c|}
\hline \multirow[t]{2}{*}{ Kromosom } & \multicolumn{4}{|c|}{ Sarapan } & \multicolumn{2}{|c|}{ Snack Pagi } & \multicolumn{4}{|c|}{ Makan Siang } & \multicolumn{2}{|c|}{ Snack Sore } & \multicolumn{4}{|c|}{ Makan Malam } \\
\hline & MP & LP & SM & $\mathrm{BH}$ & MR & $\mathrm{BH}$ & MP & LP & $\mathrm{SM}$ & $\mathrm{BH}$ & MR & $\mathrm{BH}$ & MP & LP & SM & $\mathrm{BH}$ \\
\hline 1 & 47 & 21 & 4 & 2 & 11 & 1 & 24 & 6 & 16 & 74 & 1 & 54 & 2 & 18 & 9 & 66 \\
\hline
\end{tabular}


TABEL VIII (LANJUTAN)

\begin{tabular}{ccccccccccccccccc}
\hline 2 & 47 & 21 & 4 & 2 & 11 & 1 & 24 & 6 & 16 & 74 & 1 & 54 & 27 & 25 & 1 & 74 \\
3 & 30 & 51 & 28 & 54 & 21 & 4 & 49 & 47 & 24 & 63 & 51 & 54 & 27 & 25 & 1 & 74 \\
4 & 30 & 51 & 28 & 54 & 21 & 4 & 49 & 47 & 24 & 63 & 51 & 54 & 27 & 25 & 1 & 74 \\
$\ldots$ & $\ldots$ & $\ldots$ & $\ldots$ & $\ldots$ & $\ldots$ & $\ldots$ & $\ldots$ & $\ldots$ & $\ldots$ & $\ldots$ & $\ldots$ & $\ldots$ & $\ldots$ & $\ldots$ & $\ldots$ & $\ldots$ \\
100 & 47 & 21 & 4 & 2 & 11 & 1 & 24 & 6 & 16 & 74 & 1 & 54 & 2 & 18 & 9 & 66 \\
\hline
\end{tabular}

7) Mutasi. Proses mutasi dapat dilakukan dengan membangkitkan gen secara acak dengan rentang 0-1, untuk mendapatkan gen yang termutasi dapat dilihat dari nilai Peluang Mutasi $(\mathrm{Pm})$. Jika nilai random yang dibangkitkan $<$ nilai peluang mutasi maka gen tersebut dilakukan mutasi. Nilai peluang mutasi yang sudah didefinisikan diawal yaitu 0,3 . Hasil mutasi dapat dilihat pada tabel 9.

8) Seleksi Elitis. Seleksi ini dilakukan proses perbandingan antara nilai fitness induk dengan nilai fitness anak, nilai fitness tertinggi akan menjadi kandidat solusi yang diberikan. Nilai fitness tertinggi dari 100 populasi terdapat pada kromosom ke 2 pada dengan nilai fitness 0.002135201 .

9) Kondisi Berhenti. Kondisi berhenti dapat dilihat dari batas nilai fungsi fitness dan banyak generasi. Kromosom terbaik terdapat pada kromosom ke-2 dengan nilai fitness 0.002135201 . Berikut ini menu makanan dapat dilihat pada tabel 10 .

TABEL IX

HASIL MUTASI

\begin{tabular}{cccccccccccccccccc}
\hline \multirow{2}{*}{ Kromosom } & \multicolumn{4}{c}{ Sarapan } & \multicolumn{4}{c}{ Snack Pagi } & \multicolumn{4}{c}{ Makan Siang } & \multicolumn{3}{c}{ Snack Sore } & \multicolumn{3}{c}{ Makan Malam } & \multicolumn{2}{c}{$\begin{array}{c}\text { Nilai Fungsi } \\
\text { Fitness }\end{array}$} \\
\cline { 2 - 5 } & MP & LP & SM & BH & MR & BH & MP & LP & SM & BH & MR & BH & MP & LP & SM & BH & \\
\hline 1 & 20 & 4 & 4 & 3 & 11 & 5 & 28 & 6 & 16 & 35 & 1 & 54 & 2 & 10 & 6 & 13 & 0,001341274 \\
2 & 15 & 12 & 4 & 18 & 11 & 9 & 24 & 17 & 15 & 27 & 41 & 54 & 27 & 25 & 1 & 74 & 0,002135201 \\
3 & 6 & 33 & 28 & 7 & 21 & 4 & 53 & 47 & 24 & 63 & 9 & 33 & 22 & 25 & 1 & 70 & 0,001148448 \\
4 & 11 & 51 & 28 & 24 & 21 & 4 & 49 & 37 & 24 & 63 & 51 & 54 & 27 & 4 & 1 & 74 & 0,000972706 \\
$\ldots$ & $\ldots$ & $\ldots$ & $\ldots$ & $\ldots$ & $\ldots$ & $\ldots$ & $\ldots$ & $\ldots$ & $\ldots$ & $\ldots$ & $\ldots$ & $\ldots$ & $\ldots$ & $\ldots$ & $\ldots$ & $\ldots$ & $\ldots$ \\
100 & 47 & 1 & 4 & 2 & 11 & 1 & 50 & 6 & 1 & 36 & 1 & 54 & 11 & 8 & 11 & 66 & 0,000920539 \\
\hline
\end{tabular}

TABEL $X$

HASIL KROMOSOM TERBAIK

\begin{tabular}{|c|c|c|c|c|c|c|c|c|}
\hline $\begin{array}{l}\text { Waktu } \\
\text { Makan }\end{array}$ & $\begin{array}{l}\text { Nomor } \\
\text { Kromosom }\end{array}$ & $\begin{array}{l}\text { Kode Jenis } \\
\text { Makanan }\end{array}$ & $\begin{array}{l}\text { Nama } \\
\text { Makanan }\end{array}$ & $\begin{array}{l}\text { Berat } \\
\text { Makanan }\end{array}$ & Kalori & Karbohidrat & Protein & Lemak \\
\hline \multirow[t]{4}{*}{ Sarapan } & 15 & MP & $\begin{array}{l}\text { Mie Laksa } \\
\text { Kering }\end{array}$ & 100 gram & 347 kkal & 78,2 gram & 8 gram & 0,2 gram \\
\hline & 12 & LP & $\begin{array}{l}\text { Pindang Selar } \\
\text { Kecil }\end{array}$ & 100 gram & $142 \mathrm{kkal}$ & 0 & 27 gram & 3 gram \\
\hline & 4 & SM & Bayam Kukus & 100 gram & $30 \mathrm{kkal}$ & 5,8 gram & 1,3 gram & 0,3 gram \\
\hline & 18 & $\mathrm{BH}$ & Jambu Air & 100 gram & 46 kkal & 11,8 gram & 0,6 gram & 0,2 gram \\
\hline Snack & 11 & MR & Kacang Bogor & 100 gram & $370 \mathrm{kkal}$ & 45 gram & 16 gram & 6 gram \\
\hline Pagi & 9 & BH & Bengkuang & 100 gram & $55 \mathrm{kkal}$ & 12,8 gram & 1,4 gram & 0,2 gram \\
\hline Makan & 24 & MP & Nasi Goreng & 100 gram & $138 \mathrm{kkal}$ & 15,1 gram & 1,6 gram & 1,6 gram \\
\hline \multirow[t]{3}{*}{ Siang } & 17 & LP & Buntil & 100 gram & $106 \mathrm{kkal}$ & 7,9 gram & 4,4 gram & 6,3 gram \\
\hline & 15 & SM & $\begin{array}{l}\text { Sayur Daging } \\
\text { Ayam }\end{array}$ & 100 gram & $451 \mathrm{kkal}$ & 0 & $\begin{array}{l}27,2 \\
\text { gram }\end{array}$ & 0 \\
\hline & 27 & BH & Kemang & 100 gram & 48 kkal & 11,9 gram & 1 gram & 0,2 gram \\
\hline Snack & 41 & MR & Yoghurt & 100 gram & $52 \mathrm{kkal}$ & 4 gram & 3,3 gram & 25 gram \\
\hline Sore & 54 & $\mathrm{BH}$ & Pisang Raja Uli & 100 gram & $146 \mathrm{kkal}$ & 38,2 gram & 2 gram & 0,2 gram \\
\hline Makan & 27 & MP & Nasi Uduk & 100 gram & $152 \mathrm{kkal}$ & 7 gram & 2,6 gram & 2,6 gram \\
\hline \multirow[t]{3}{*}{ Malam } & 25 & LP & Pepes Tauco & 100 gram & 184 kkal & 22,2 gram & $\begin{array}{l}11,4 \\
\text { gram }\end{array}$ & 5,5 gram \\
\hline & 1 & SM & $\begin{array}{l}\text { Gudangan } \\
\text { (Urapan) }\end{array}$ & 100 gram & 84 kkal & 12,6 gram & $\begin{array}{l}2,76 \\
\text { gram }\end{array}$ & $\begin{array}{l}3,42 \\
\text { gram }\end{array}$ \\
\hline & 74 & $\mathrm{BH}$ & Jus Melon & 100 gram & $47,1 \mathrm{kkal}$ & 12,1 gram & 0,2 gram & 0,1 gram \\
\hline
\end{tabular}




\section{Implementasi Sistem} 5.

Implementasi sistem dapat dilihat pada gambar 4 dan

Gambar 4 merupakan tampilan halaman pilih aktivitas. Setelah ibu hamil memiliki akun dan dapat login, ibu hamil dapat memilih aktivitas yang terdiri dari aktivitas yang sudah ditentukan dalam 1 hari seperti, tidur, perawatan diri, makan, memasak dan lainnya. Masing-masing aktivitas memiliki durasi waktu sesuai dengan aktivitas yang dilakukannya dalam waktu 24 jam untuk mendapatkan rekomendasi makanan.

Gambar 5 merupakan tampilan halaman rekomendasi makanan untuk ibu hamil. Makanan yang direkomendasikan akan muncul setelah ibu hamil memilih aktivitas pada gambar 4. Pada halaman rekomendasi makanan terdiri dari jumlah kebutuhan kalori yang dibutuhkan oleh ibu hamil, jumlah kalori yang direkomendasikan oleh sistem, dan menu makanan berdasarkan waktu makan (sarapan, makan siang, makan malam, snack pagi dan snack sore). Untuk mempermudah ibu hamil menyiapkan makanan, setiap makanan diberikan informasi jumlah berat makanan yang harus dikonsumsi dan jumlah kalori makanan tersebut.

\section{Pengujian Validasi}

Pengujian validasi dilakukan untuk melihat nilai validitas dari sistem yang dibangun. Pengujian dilakukan dengan membandingkan hasil yang diberikan oleh sistem dengan hasil pakar. Sampel data ibu hamil yang digunakan yaitu 20 data yang memiliki kriteria normal, anemia, diabetes gestasional dan hipertensi. Berdasarkan pengujian yang telah dilakukan, metode Algoritma genetika dapat memberikan hasil 91\% rekomendasi makanan mendekati jumlah kalori yang sesuai dengan kebutuhan dan 9\% tidak sesuai dengan kalori yang dibutuhkan oleh ibu hamil, karena memiliki perbedaan kalori yang cukup jauh berbeda.

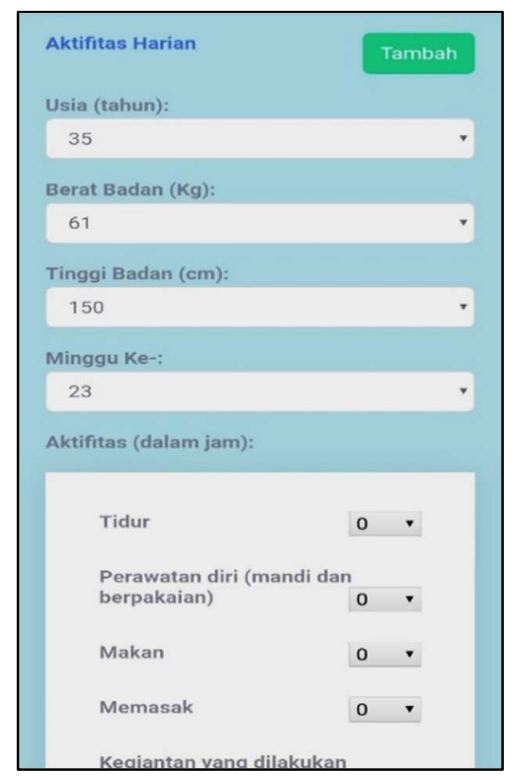

Gambar 4. Halaman Pilih Aktivitas

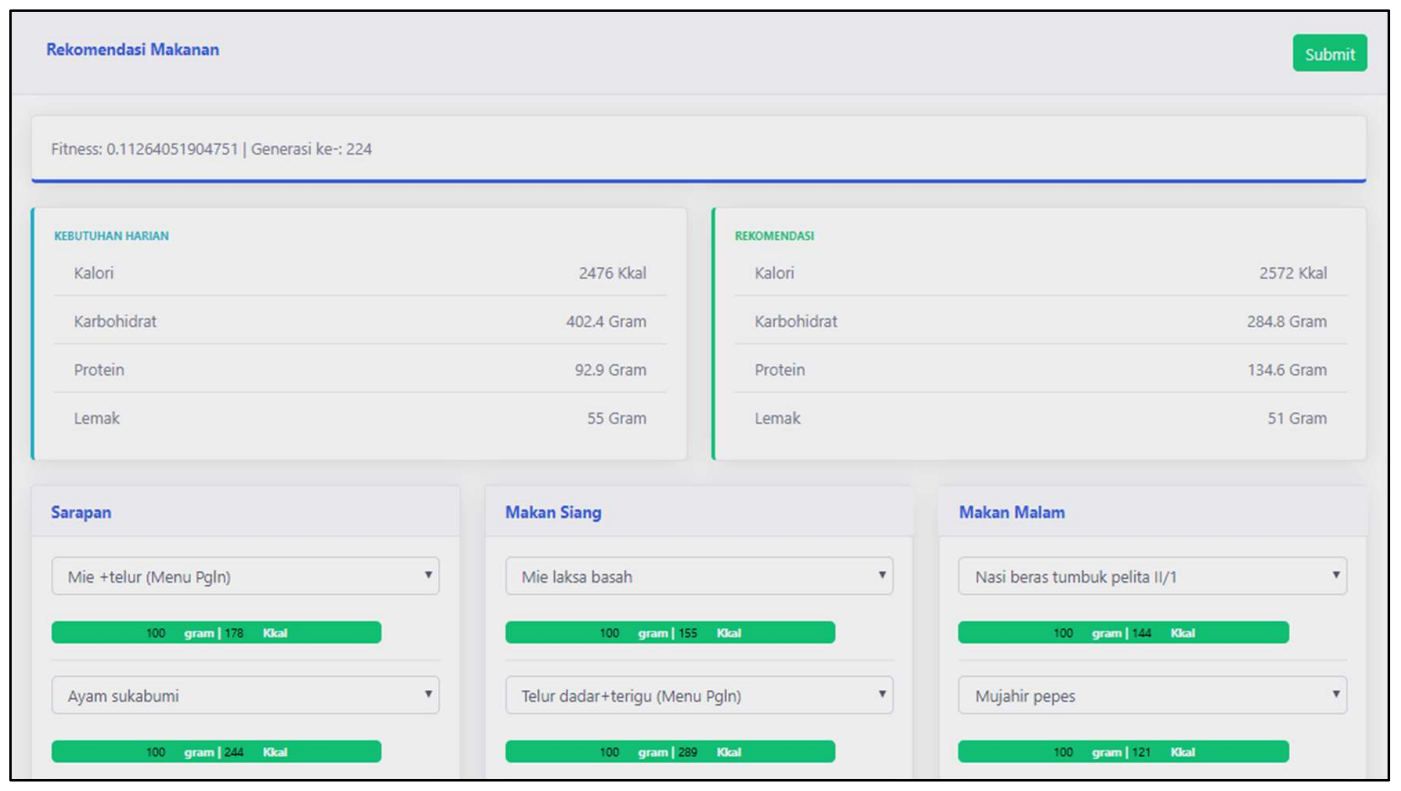

Gambar 5. Rekomendasi Makanan Ibu Hamil 


\section{PENUTUP}

Kesimpulan yang diperoleh dari penelitian ini yaitu sistem informasi gizi ibu hamil dapat memberikan informasi rekomendasi makanan yang optimal dan variatif sesuai dengan aktivitas yang dilakukan, trimester kehamilan dan kondisi klinis ibu hamil. Rekomendasi makanan tersebut dibagi menjadi 5 waktu makan, yaitu sarapan, snack pagi, makan siang, snack sore dan makan malam.

\section{DAFTAR PUSTAKA}

[1] A. Wibowo, "Perancangan Aplikasi Konsultasi Ibu Hamil berbasis Cloud Computing," Ultim. InfoSys, vol. IX, no. 1, pp. 1-8, 2018.

[2] S. Fathonah, Gizi \& Kesehatan untuk Ibu Hamil Kajian Teori \& Aplikasinya. Jakarta: Penerbit Erlangga, 2016.

[3] A. Ernawati, "Masalah gizi pada ibu hamil," Litbang, vol. XIII, no. 1, pp. 60-69, 2017.

[4] N. K. Sari, M. Hakimi, and T. B. Rahayujati, "Determinan gangguan hipertensi kehamilan di Indonesia," BKM Jourrnal Community Med. Public Heal., vol. 32, no. 9, pp. 295-302, 2016.

[5] Suharni, H. Lestari, and R. T. Ardiansyah, "Perilaku pencari pengobatan pada ibu hamil terhadap keluhan sakit selama kehamilan di wilayah kerja Puskesmas Tampo Kecamatan Napabalano Kabupaten Muna Tahun 2016," J. Ilm. Mhs. Kesehat. Masy. Unsyiah, vol. 1, no. 3, 2016.

[6] Muhdar, Rosmiati, G. T. Tulak, E. Saputri, and R. W. Susanti, "Peningkatan pengetahuan tentang pencegahan stunting pada wanita usia subur, ibu hamil dan ibu balita di kecamatan polinggona," J. Ilm. Pengabdi. Kpd. Masy., vol. 3, no. 2, pp. 142-148, 2019.

[7] E. Krisnanik and V. Indriasari, "Desain model sistem pakar menu sehat wanita hamil berdasarkan gizi menggunakan metode cooper," JTIIK, vol. 5, no. 6, pp. 643-652, 2018.

[8] B. R. Musanah and W. F. Mahmudy, "Optimasi kebutuhan gizi untuk ibu hamil dengan menggunakan hybrid algoritma genetika dan simulated annealing," $J$. Pengemb. Teknol. Inf. dan Ilmu Komput., vol. 3, no. 4, 2019.

[9] I. Ardiansah and M. T. Koeryaman, "Rancang Bangun Sistem Informasi Berbasis Web Sebagai Panduan dan Rekam Data Nutrisi Ibu Hamil," J. Ilm. KOMPUTASI, vol. 17, no. 2, pp. 95-108, 2018.

[10] Z. Zukhri, ALGORITMA GENETIKA: Metode Komputasi Evolusioner untuk Menyelesaikan Masalah Optimasi. Yogyakarta: Penerbit ANDI, 2014.

[11] G. A. Pamungkas et al., "Pembuatan aplikasi panduan gizi seimbang berbasis android dengan menggunakan metode b ackward chaining," J. Teknol. dan Sist. Komput., vol. 4, no. 2, pp. 369-379, 2016.

[12] FAO, WHO, and UNU, "Human energy requirements," vol. 0, 2001.

[13] S. A. Fajar, Buku Saku Gizi. .

[14] I. Darusman, "Sistem Informasi Pemenuhan Nutrisi pada Masa Kehamilan Menggunakan Metode Harris Benedict," Skripsi, pp. 1-11, 2016.

[15] J. Hasyir, "Implementasi Algoritma Genetika untuk Optimasi Komposisi Makanan bagi Penderita Kanker Limfoma," 2019. 
JUITA: Jurnal Informatika e-ISSN: 2579-8901; Volume 8, Nomor 1, Mei 2020 